\title{
Unusual thick eolian sand sheet sedimentary succession: Paleoproterozoic Bandeirinha Formation, Minas Gerais
}

\author{
Insólita espessura de uma sucessão de lençol de areia: \\ Formação Bandeirinha, Proterozoico, Minas Gerais
}

Fábio Simplicio ${ }^{1 *}$, Giorgio Basilici ${ }^{1}$

\begin{abstract}
Some present-day eolian sand sheets have small and width dunes, called zibars, as common type of depositional morphology. Their formation is related to different stabilizing factors, which reduce the availability of clastic materials for eolian processes. In fact, zibars are dunes which do not have time to develop a larger dune with slipface (proto-dune). Dunes in sands sheet areas generally are constructed by wind ripple laminations and commonly generate sedimentary succession less than $20 \mathrm{~m}$ thick, which are the consequence of low sand supply. This study deals with an uncommon eolian sand sheet sedimentary succession more than $50 \mathrm{~m}$ thick, Proterozoic in age, known as Bandeirinha Formation. This paper tries to explain the anomalous thick of this sand sheet sedimentary succession. High thickness was probably the result of a high input of sand material, combine with low availability of sand, thus allowing the only construction of proto-dunes (zibars). Early cementation, due to near-surface evaporation of saline water, has been proposed as main factor that reduced the sand availability into this eolian system. Finally, the subsidence processes related to the first stage of rift Espinhaço Basin must have generated the accommodation space to preserve the sand sheet succession.
\end{abstract}

KEYWORDS: Eolian sand sheet; zibar; ephemeral channel rivers; Bandeirinha Formation; Paleoproterozoic.
RESUMO: Em alguns lençóis de areia eólica atuais existem dunas pequenas e largas, chamadas zibars, como tipo comum de morfologia deposicional. Sua formação é relacionada a diferentes fatores de estabilização, os quais reduzem a disponibilidade de materiais clásticos para os processos eólicos. De fato, os zibars são dunas que não tiveram tempo para se desenvolver como grandes dunas (protodunas). As dunas dos lençóis de areia (zibars) geralmente são construidas por laminaçöes de marcas onduladas de vento e comumente geram sucessóes com menos de $20 \mathrm{~m}$ de espessura, consequência da baixa oferta de sedimento. Este estudo trata de uma sucessão sedimentar com depósitos de lençóis de areia de espessuras incomuns, com mais do que $50 \mathrm{~m}$ de espessura, encontrados na Formação Bandeirinha, de idade Proterozoica. Este trabalho tenta explicar essas espessuras anômalas de depósitos de lençol de areia. A elevada espessura desses depósitos deve-se provavelmente ao grande aporte de material clástico no sistema, combinado com a baixa disponibilidade de sedimentos, que não permitiu a formação de dunas com faces de deslizamento, mas somente de protodunas (zibars). Cimentação precoce, causada pela evaporaçấo de água salina próxima à superficie, tem sido proposta como principal fator para a redução da disponibilidade de areia neste sistema eólico. Finalmente, os processos de subsidência relacionada aos primeiros estágios de rifteamento da Bacia Espinhaço devem ter gerado o espaço de acomodaçáo para preservar a sucessão de lençol de areia.

PALAVRAS-CHAVE: Lençol de areia; zibar; rios efêmeros; Formaçāo Bandeirinha; Paleoproterozoico.

IIInstitute of Geosciences, Universidade Estadual de Campinas - UNICAMP, Campinas (SP), Brasil. E-mails: fabio.simplicio@ige.unicamp.br; basilici@ige.unicamp.br *Corresponding author.

Manuscript ID: 30133. Received: 07/16/2014. Approved: 06/06/2015. 


\section{INTRODUCTION}

Eolian sand sheet depositional systems are flattened areas where the main bedforms are wind ripples, slipfaceless dunes (zibars and nabkhas) and more rarely slipfaced dunes. Poor availability of clastic material is main responsible factor to not form slipfaced dunes (Nielson \& Kocurek 1986; Lea \& Waythomas 1990). Poor availability of sand for wind transport and deposition is controlled by vegetation, which constitutes an obstacle to the wind, water table, causing cohesion of the grains, abundance of coarse-grained sands or granules, cemented depositional surface, and seasonal flooding that causes cohesive muddy covering (Kocurek \& Nielson 1986; Clemmensen \& Dam 1993; Chakraborty \& Chakraborty 2001; Basilici \& Dal Bó 2014). More recently, studies in the Arctic and Antarctic areas have pointed out that the ice can be an important factor to poor availability of sand (Lea \& Waythomas 1990; Bristow et al. 2010). All these factors may be considered for Precambrian eolian sand sheet deposition with exception to vegetation factor, which appeared on the earth surface only after Silurian (Clemmensen \& Dam 1993).

Present-day eolian sand sheets are areas of deposition or deflation, which occur in warm or cold, arid or semiarid climates (Kocurek \& Nielson 1986; Mountney \& Russell 2004; Mountney 2006; Basilici \& Dal Bó 2014). The deflation areas generate deposits constituted by granule or gravel lags, whereas the depositional areas are predominantly constituted by nabkhas and/or zibars and rare slipfaced dunes. Present nabkhas are associated to vegetation, thus their presence in Precambrian eolian systems should be excluded. Zibars probably resulted to be most common dunes in Precambrian eolian sand sheets depositional systems. Zibars, which are also considered proto-dunes (Nielson \& Kocurek 1986), are described in present-day eolian sand sheet environments, but their recognition in the geological record is not clear. Sets of wind ripple laminations, separated by erosive truncation surfaces, are the main depositional expression of zibars and nabkhas deposits (Kocurek \& Nielson 1986; Lea \& Waythomas 1990; Mountney \& Russel 2004; Bristow et al. 2010; Basilici \& Dal Bó 2014).

Ancient eolian sand sheets are typically less than $20 \mathrm{~m}$ thick (Mountney 2006), as these environments are characterized by low sand supply. However, the Bandeirinha Formation, a sedimentary succession c. $250 \mathrm{~m}$ thick, is composed by four intervals of sand sheet deposits, each one more than $50 \mathrm{~m}$ thick. These intervals are interbedded with $1.5-18 \mathrm{~m}$ thick sandy conglomerates, interpreted as deposits of highly concentrated river flows. The aim of this paper was to discuss the reasons which have induced the accumulation of this unusually thick eolian sand sheet succession.

\section{GEOLOGICAL SETTING}

The Bandeirinha Formation is the lowermost unit of Espinhaço Supergroup, deposited into a homonymous Paleoproterozoic Basin, located in a wide area between the San Francisco Craton and the Araçuaí fold and thrust belt (Fig. 1A) (Almeida 1977; Chaves \& Brandão 2004). The Bandeirinha Formation crops out near the Diamantina city, in Minas Gerais (Fig. 1B).

An extensional event at Statherian age $(1.8-1.6 \mathrm{Ga})$, which generated a lithospheric stretching and subsequent break-up of the São Francisco-Congo Craton, is supposed to have been the responsible mechanism of the creation of accommodation space in the Espinhaço Basin (Alkmin \& Marshak 1998). Chemale et al. (2012) and Santos et al. (2013) consider two phases of basin evolution. The first phase developed according to N-S faultblock activity that created a rift basin, and the second phase related to flexural subsidence, which was associated to thermal process (Martins-Neto 2000; Chemale et al. 2012). The Espinhaço Supergroup is subdivided in Diamantina and Conselheiro Mata groups (Dussin \& Dussin 1995). The lower Diamantina Group is composed of Bandeirinha, São João da Chapada, Sopa-Brumadinho and Galho do Miguel formations (Fig. 1B) (Fogaça et al. 1984; Silva 1998; Martins-Neto 2000; Chemale et al. 2012). The Bandeirinha Formation (1.7 - 1.8 Ga; Chemale et al. 2012) is c. $250 \mathrm{~m}$ thick mostly composed of laminated sandstone packages interbedded with three conglomerate beds (Fig. 2). This litostratigraphic unit was previously interpreted by Silva (1998) as result of coastal and braided river depositional process, where the interbedded conglomerate beds represented mainly mass flow deposits in proximal areas of alluvial fans, related to tectonic activity. Simplicio (2013) proposed a paleoenvironmental model in which sandstones were deposited in sand sheet context and conglomerates correspond to deposition in ephemeral streams.

The Bandeirinha Formation is weakly to moderately deformated and metamorphized unit, with beds dipping toward NE of $25-35^{\circ}$. Beds geometry and primary sedimentary structures are well preserved, thus sedimentological terminologies are used. 


\section{METHOD}

A stratigraphic section of more than $250 \mathrm{~m}$ thick was measured in type area of Bandeirinha Formation (Fig. 2). Detailed facies analysis, based on grain-size, sorting, type and organization of the sedimentary structures, form and dimension of the beds, characteristics of the bounding surfaces, lateral and vertical variation of lithofacies, and interpretation of the depositional mechanisms, was applied to the measured section (Miall 1985; Walker 2006).

\section{SEDIMENTOLOGICAL ANALYSIS}

The sedimentary succession of the Bandeirinha Formation is formed of eolian deposits, constituted by laminated and cross-stratified sandstone facies and fluvial deposits, constituted by sandy conglomerate facies.

\section{Laminated sandstone}

Laminated sandstone is formed of bimodal fine- to coarse-grained reddish to white sandstone, moderately to well-sorted, with rounded to well-rounded grains. Planar to low-angle inclined (up to $10^{\circ}$ ), parallel laminations, are the dominant sedimentary structures (Fig. 3A). The laminae are $2-12 \mathrm{~mm}$ thick with grain-size segregation and sometimes characterized by inverse grading; they are similar to the "pin stripe lamination" described by Fryberger and Schenk (1988) (Fig. 3B). Laminated sandstone sets, $0.4-2.0 \mathrm{~m}$ thick, laterally extended 4 to more than $9 \mathrm{~m}$, are vertically and laterally overlapped. The bounding surfaces of the sets are erosive, $0-15^{\circ}$ dipping, and are parallel to the laminae of the overhead set (Fig. 3A). Locally, asymmetrical undulating laminations may be observed in gradual transition with the planar laminations (Fig. 3C). The laminated sandstone sets constitute

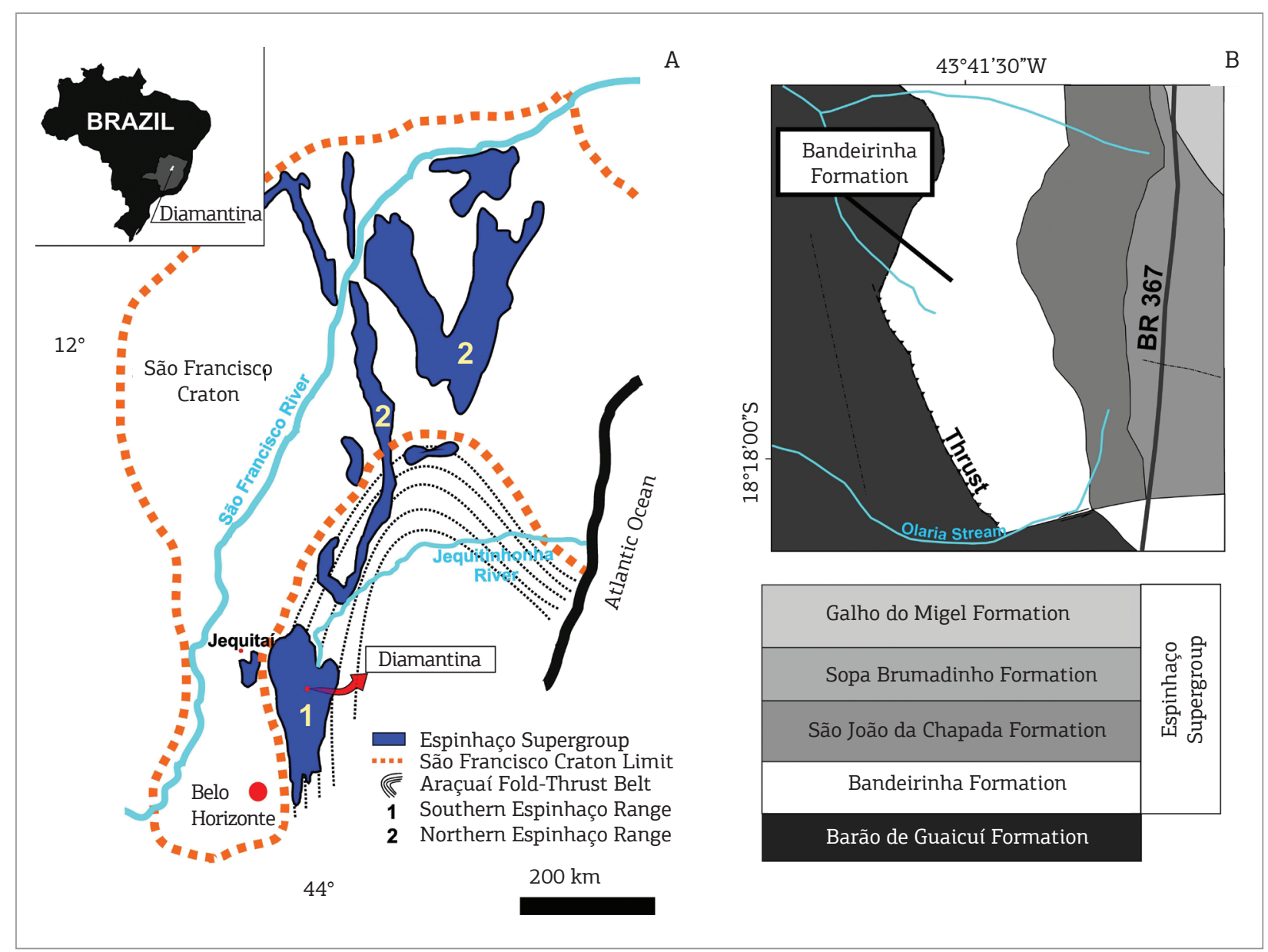

Figure 1. Geographical location of the Espinhaço Supergroup relative to São Francisco Craton and Araçuaí fold and thrust belt. (A) The Diamantina region is located in the middle of the Southern Espinhaço Range. (B) Geological map of the study area, which is located $10 \mathrm{~km}$ towards SW from the Diamantina city (see Fig. 2). Modified from Chaves and Brandão (2004), Lopes-Silva and Knauer (2011). 


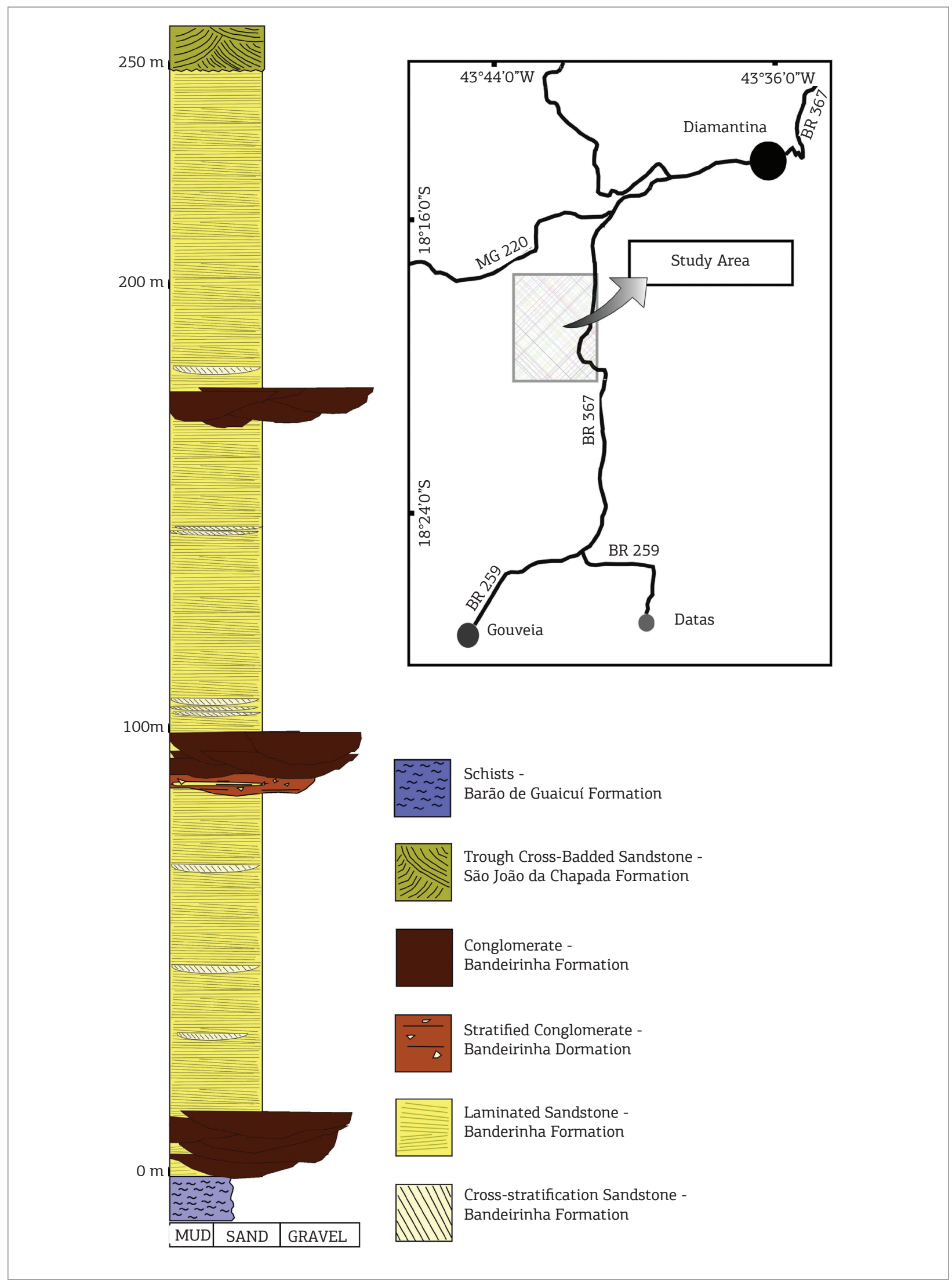

Figure 2. Stratigraphic section of Bandeirinha Formation in the study area. Note the three sandy conglomerate beds interbedded with laminated sandstone. The bottom contact corresponds to the Barão de Guaicuí Formation and the upper boundary with trough cross-stratification sandstones to the São João da Chapada Formation. 
$84 \%$ of the thickness of the measured succession and form interval more than $50 \mathrm{~m}$ thick.

Horizontal or low-angle planar and parallel laminae are interpreted as subcritical climbing translatent strata (Hunter 1977; Hunter 1981) (Figs. 3A and 3B). This sedimentary structure is produced by migration of climbing wind ripples. The similarity with the "pin stripe lamination" of Fryberger and Schenk (1988), the grain-size segregation (Eriksson \& Simpson 1998) and the presence of high rounded sandstone clasts, typical of wind transport (Mahaney 2002), suggest this interpretation. Also the architectural framework, in which the laminated sandstone sets are separated by inclined $\left(<15^{\circ}\right)$ bounding surfaces (truncation surfaces), supports this interpretation (Kocurek \&

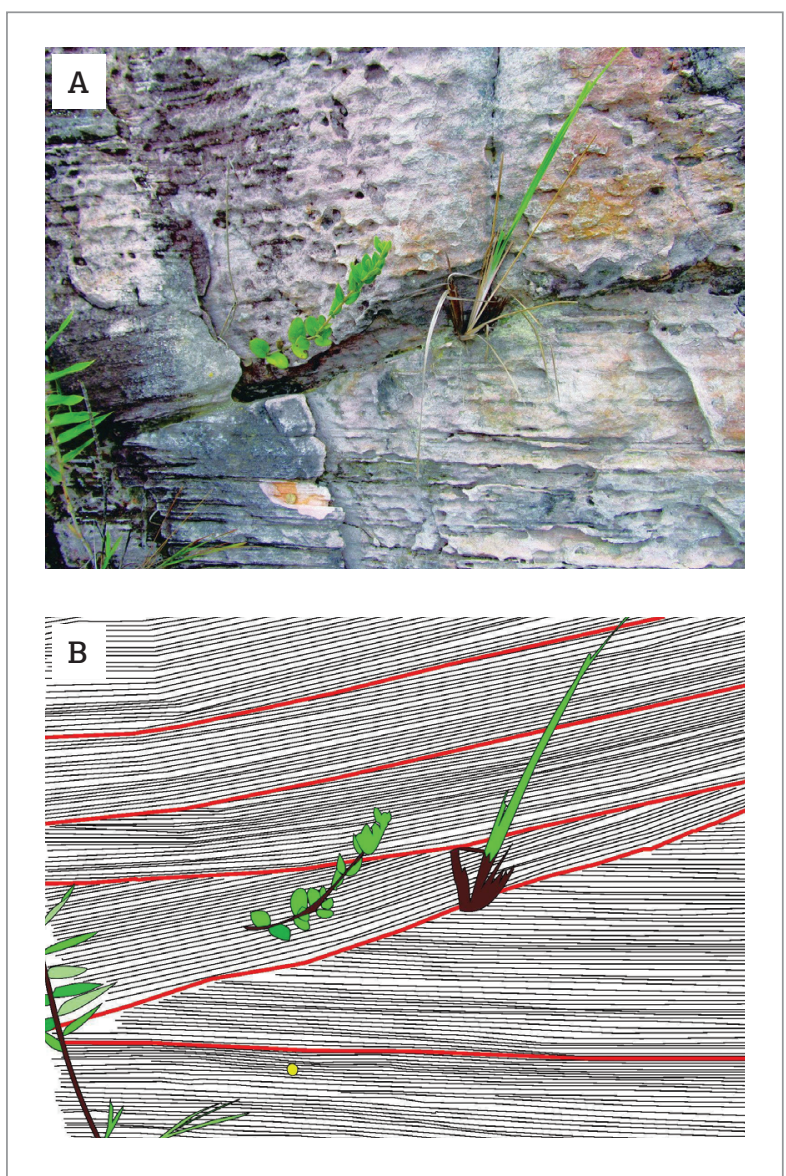

Figure 3. Laminated sandstone. (A) Low-angle, parallel laminated sandstone, corresponding to subcritical translatent climbing strata, organized in sets separated by erosive surfaces (red lines indicate truncation surfaces). (B) Observe the grainsize segregation highlight the planar and parallel laminations (arrows point the fine-grained laminae). (C) Asymmetrical undulating laminations (dotted rectangle) in gradual transition with planar and parallel laminations. Pencil: $14 \mathrm{~cm}$.
Nielson 1986). The asymmetrical undulating laminations are considered supercritically climbing translatent strata related to the increase of deposition rate (Hunter 1977) similar to interpreted for Basilici and Dal Bó (2014) in Tulum Valley (Argentina).

\section{Cross-stratified sandstone}

Well- to very well-sorted, very fine- to fine-grained sandstone characterizes this facies. Cross-stratified sets, $0.12-0.3 \mathrm{~m}$ thick, $3-7 \mathrm{~m}$ laterally extended, constitute the sedimentary structure (Fig. 4). The foreset laminae are $2-10 \mathrm{~mm}$ thick, and $\operatorname{dip} 21-26^{\circ}$. The foresets display alternation of fine- and very fine-grained laminae. Reactivation surfaces (sensu Brookfield 1977) are also observed. This facies forms lenticular and isolated beds, which are embedded in laminated sandstone sets with erosive contact. Cross-stratified sandstone corresponds to $2 \%$ in thickness of the measured sandstone succession.

Cross-stratified sandstone indicates that this deposit was formed for avalanching processes, allowing its interpretation as lee side of small dunes. The fine- and very finegrained foreset laminae, the interbedding with wind-rippled strata, the presence of reactivation surfaces and the absence of sedimentary structures associated to subaqueous flows suggest that these structures are eolian dunes (Hunter 1977; Kocurek 1996; Mountney 2006). Real height of the dunes is unknown because the erosive boundary surfaces, but the restricted lateral extension and rare occurrence of this structure suggests small dimension of the original bedforms.

\section{Sandy conglomerate}

Sandy conglomerate facies has an erosive and slightly concave-up bottom surface and planar top surface. Two types

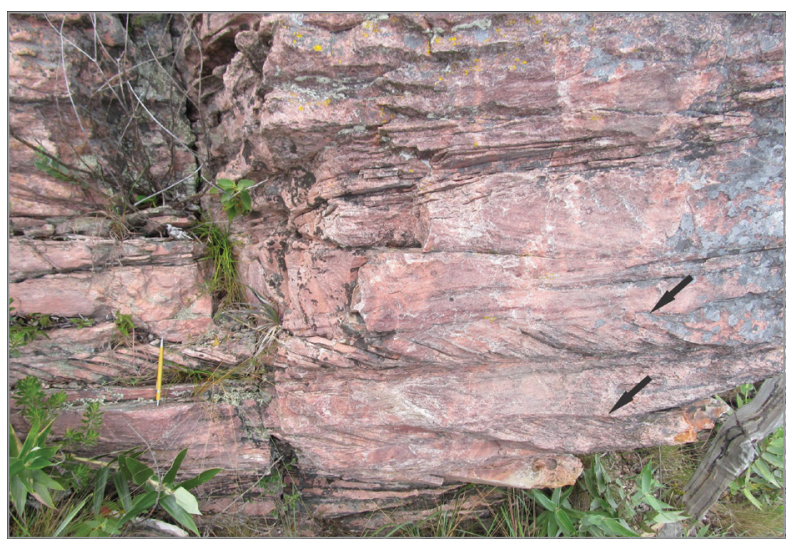

Figure 4. Cross-stratified sandstone facies (arrows) interbedded with laminated sandstone facies. 
of sandy conglomerate subfacies are present: structureless sandy conglomerate and stratified sandy conglomerate (Fig. 5A). The structureless sandy conglomerate represents $12 \%$ of the thickness of the sedimentary succession; it is constituted of poorly sorted, clast-supported, pebble- to boulder-grained conglomerate within medium- to coarsegrained sandstone, poorly sorted matrix. The thickness of this lithofacies is $7-18 \mathrm{~m}$, its bounding surfaces are erosive and concave-up, and its upper surface, when it is in contact with translatent climbing ripples strata, has bounding surface planar and probably non-erosive. The conglomerate clasts are constituted of laminated sandstone facies (Fig. 5B), whose abundance is $87-100 \%$, and the others clasts (vein-quartz, quartzite, banded iron formation and schist), whose abundance is $13-0 \%$. Laminated sandstone clasts are angular to rounded, with prevalence of subangular (Fig. 5B); the other clasts are rounded or subrounded. The dimension of the clasts is extremely variable. Maximum particle size of laminated sandstone clasts is $0.35 \mathrm{~m}$. The other clasts have maximum particle size of $0.09 \mathrm{~m}$. This subfacies does not display any internal organization.

Stratified conglomerate is less than $1.5 \mathrm{~m}$ thick, and it constitutes $2 \%$ of the thickness of the measured sedimentary succession. Maximum particle size of the clasts is $0.14 \mathrm{~m}$; the matrix is a medium- and coarse-grained, poorly-sorted sandstone, and it is more abundant than structureless sandy conglomerate. Roundness and composition of the clasts are similar to the other lithofacies. The beds of this lithofacies are commonly interbedded with fine- and medium-grained, well sorted, inverse grading

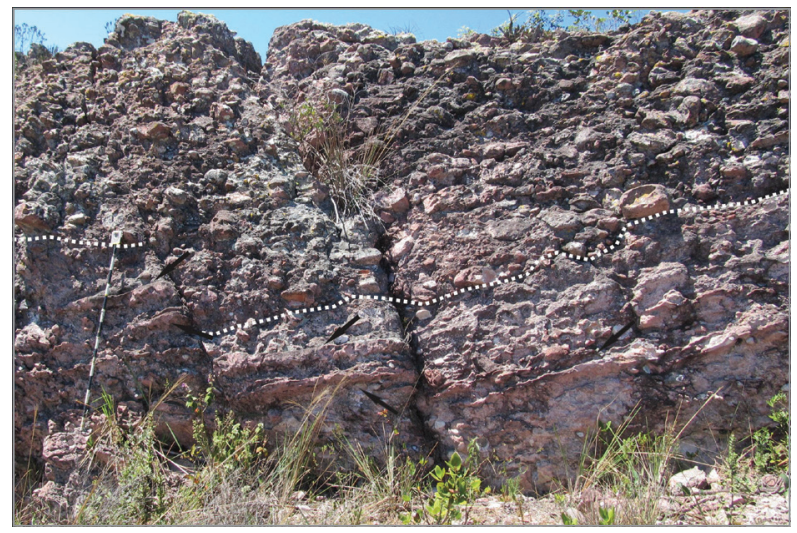

Figure 5. Sandy conglomerate facies. (A) The dashed line indicates the contact between stratified sandy conglomerate subfacies and structureless sandy conglomerate subfacies. The lenticular sandstone beds are indicated by arrows. (B) Sandstone clasts (rounded to angular) - Pencil: $14 \mathrm{~cm}$. (C) The detailed scale to observe the sandstone beds - Jacob stick: $1.5 \mathrm{~m}$. laminated sandstone, $0.04-0.15 \mathrm{~m}$ thick, which form lenticular beds laterally extended up to $3 \mathrm{~m}$ (Fig. 5A and 5C). These sandstone beds have gradual transition at the base to sandy conglomerate, but the top surface is sharp and smooth (Fig. 5C). The sandstone beds display planar parallel laminations, constituted of laminae $3-10 \mathrm{~mm}$ thick, at times with inverse grading.

The concave-up bottom and the planar top surface of the sandy conglomerate are evidences that this facies represents the filling of channelized morphological structures, generated by subaqueous flows. The grain-size heterogeneity and the absence of internal structures of the conglomerate subfacies suggest highly concentrated subaqueous flows as depositional mechanisms (Tooth 2000; Rodriguéz-Lopez et al. 2012). More diluted subaqueous flows deposited the stratified sandy conglomerate subfacies. Most of the clasts that constitute these deposits were originated by the erosion of the substratum, constituted of laminated sandstone. This demonstrates that laminated sandstone had certain degree of competence before the transport (Trewin N.H. 1993; Mountney \& Howell 2000). Angular or subangular roundness of these clasts means that the laminated sandstone clasts (intraclasts) did not undergo a long transport. The rounded exotic clasts indicate that the catchment area was external to the depositional basin.

Two hypotheses are possible to explain the laminated sandstone beds associated with stratified sandy conglomerate. These deposits may correspond to subaqueous or eolian deposits. If interpreted as subaqueous deposits they represent parallel laminations formed in upper flow regime (Fielding 2006). However, we do not observed parting laminations and laminae with normal grading, which are characteristics of this structure. Thus, we propose an eolian origin for these laminae due to clasts dimensions, sorting and inverse grading, consequently these laminae are interpreted as wind ripple laminations. Indeed, sand reworking by wind inside ephemeral channels in dry periods is very common (Cowan 1993; Tooth 2000; Jain et al. 2005; Krapf et al. 2005).

\section{DISCUSSION}

\section{Paleoenvironment analysis}

The Bandeirinha Formation is constituted by a monotonous sedimentary succession, composed by laminated sandstone with small lenticular cross-stratified sandstone sets, and sandy conglomerate (Fig. 2). Laminated sandstone deposits are interpreted as climbing wind ripples, 
cross-stratified sandstone as small eolian dunes, while sandy conglomerate were produced by ephemeral stream flows. The depositional environment is interpreted as dry eolian sand sheet, which was episodically occupied by ephemeral river systems that cut through the depositional surface. Laminated sandstone facies were probably part of zibar-like dunes (Fig. 6) and cross-stratified sets corresponded to small and isolated slipfaced dunes (Kocurek \& Nielson 1986; Nielson \& Kocurek 1986; Mountney $\&$ Russell 2004). Zibars are bedforms considered dunes which do not have time to fully develop (proto-dunes), their internal architecture is composed by low-angle or tabular sets separated by truncation surface (Nielson $\&$ Kocurek 1986; Bristow et al. 2010). This eolian sand sheet was characterized by abundance of zibar dunes, as well as many present-day eolian systems (Nielson \& Kocurek 1986; Wang et al. 2009). Nielson and Kocurek (1986) analyzed zibars deposits in a sand sheet area from Entrada Sandstone Formation and observed that slipfaced dunes deposits had to fine- to medium-grained sand $(0.1-0.3 \mathrm{~mm})$ and the zibars fine- to coarse -grained sand $(0.1-1.0 \mathrm{~mm})$ and claimed that this grain-size may be an important factor to preventing the slipfaced dunes formation. Laminated sandstones deposits of Bandeirinha Formation have analogous grain-size of zibar described by Nielson and Kocurek (1986) suggesting an analogous interpretation of this facies. In present day, zibar dunes are common in sand sheet areas that are near to dune fields where the clastic input is high, but the availability is low, to form slipfaced dunes (Nielson \& Kocurek 1986). The availability depends not only on the input but on other factors that limit the quantity of loose sand due to the creation of protection surfaces, as well as the effect of water table rise and capillarity fringe action, which aggregate sand, coarse to pebble grained materials concentration, that shield the surface, early cementation, freezing and seasonal flooding (Kocurek \& Nielson 1986; Basilici \& Dal Bó 2014).

The Bandeirinha Formation is a sandstone succession deposited in eolian-dominated paleoenvironment interbedded with three ephemeral fluvial episodes (Fig. 2). Eolian processes predominated for long time and they were interrupted by fluvial ephemeral systems (Fig. 6). During the fluvial episodes, the increase of precipitations inhibited the eolian processes of transport and sedimentation, and formed fluvial channels that cannibalized previous eolian deposits, bringing about the filling of the channels with sandstone intraclasts. Probably the alternation between eolian and fluvial episodes has climatic causes, as related by Trewin (1993) and Mountney and Howell (2000).

\section{Unusual high thickness of the eolian sand sheet succession}

Eolian sand sheet sedimentary successions are commonly less than $20 \mathrm{~m}$ thick (Mountney 2006), because these depositional systems are transitional to dune fields or because geographic position difficult their accumulation (e.g. proximity to river systems). Chakraborty and Chakraborty (2001) considered the Shikaoda Formation (Hosangabad, India), $40 \mathrm{~m}$ thick, a thicker eolian sand sheet deposits that has been recognized. These authors noted that the eolian system developed in supratidal setting, in which the sand sheet area was affected, directly or indirectly, by the tides, as suggested by subaqueous structures, adhesion strata, and evaporites deposits. Chakraborty and Chakraborty (2001) concluded that frequent tidal flooding dampen the sand, supplied by the coastal setting, thus inhibiting the availability of sand and the consequent construction of slipfaced dunes.

Differently from the Shikaoda Formation, the eolian sand sheet succession of the Bandeirinha Formation does not have subaqueous deposits, mud cracks or adhesion structures that may indicate subaqueous processes, flooding and high humidity surface (Nielson \& Kocurek 1986;

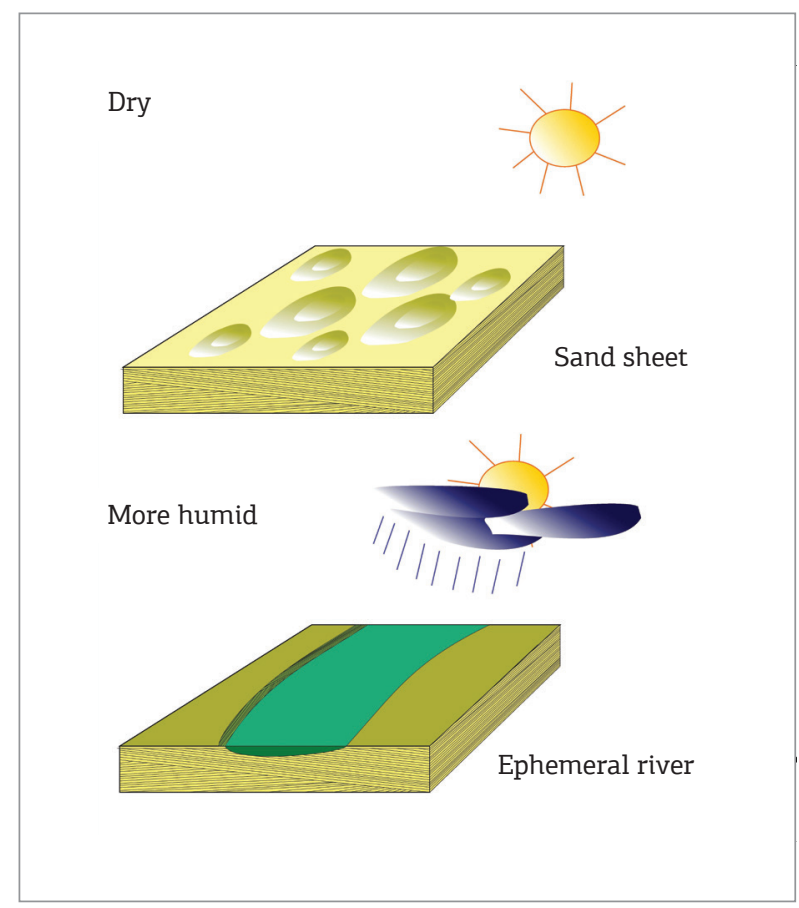

Figure 6. The interbedding between laminated sandstone and sandy conglomerate facies is interpreted as due to alternating climate phases, where laminated sandstone, which represents an eolian sand sheet with zibars bedforms, formed in dry phase and sandy conglomerate, that represent a river channel filling, is related to more humid periods. 
Clemensen \& Dam 1993; Rodriguéz-Lopez et al. 2010; Basilici \& Dal Bó 2014). However, alike to the Shikaoda Formation, the eolian sand sheet sedimentary succession of the Bandeirinha Formation is characterized by a high thickness, which suggests high sandy supply. In general, when an eolian system receives large input of sediment slipfaced dunes form (Kocurek \& Nielson 1986). Nevetheless, Bandeirinha Formation shows rare dunes with slipface, testifying low availability of sand. To explain the apparent inconsistency between high supply and low availability of sediment, two other factors may be invoked according to recorded features: early cementation of the sand and coarse grain-size. Early cementation of the sand, soon after the deposition, was probably the main control factor that allowed the accumulation of these sand materials and its poor availability. This is suggested by the sandy conglomerate facies, which is constituted by intraclasts of laminated sandstone. Stream flow cannibalized the previously cemented eolian sand sheet deposits, which furnished the main clastic source of the fluvial conglomerates, indicating the sand materials were been subjected to early cementation processes. In dry and hot continental environments, where the evaporation exceeds the meteoric influx, the groundwater flux is upward directed, facilitating the mineral precipitation (Worden \& Burley 2003). Similar interpretation was described by Rodriguéz-Lopez et al. 2012 to explain the origin of sandy intraclast in eolian Teruel Basin (Spain). Early cementation may be due to evaporitic mineral precipitation, as observed by Basilici and Dal Bó (2014) in present sand sheet deposits, but the later metamorphism and diagenesis masked or modified previous evaporite cements of Bandeirinha Formation.

In conclusion, early cementation is recognized as an important factor that determined the accumulation of the sandstone. The preservation of Bandeirinha Formation was possible by accommodation space that placed eolian accumulation below the erosional base level (Kocurek \& Havholm 1993). Accommodation space was related to high subsidence rate attributed to the early stages of rift evolution proposed for Espinhaço Basin (Dussin \& Dussin 1995; Silva 1998; Martins-Neto 2000; Chemale et al. 2012).

\section{CONCLUSIONS}

The Bandeirinha Formation is constituted of a sandstone succession interbedded with three sandy conglomerate episodes. Sandstone beds are deposited in an eolian sand sheet paleoenvironment, whereas the sandy conglomerate beds were formed in ephemeral river channels for highly concentrated subaqueous flows. Probably, alternating climate phases, dry and more humid, were responsible for sand sheet and fluvial depositional palaeoenvironments, respectively. The anomalous thickness of the eolian sand sheet deposits was due to high supply of sand material combined with early cementation of the sand, which decreased the sand availability and caused the accumulation of low and wide dunes (zibar). High rate of subsidence associated with an extensional tectonic phase enabled the eolian sand sheet preservation.

\section{ACKNOWLEDGEMENT}

The authors gratefully acknowledge the Capes for financial support. We would like to thank also Mrs. Carmem and Mr. Rommel, wonderful employees of the Casa da Gloria in Diamantina.

\section{REFERENCES}

Alkmim F.F. \& Marshak S. 1998. Transamazonian Orogeny in the Southern São Francisco Craton Region, Minas Gerais, Brazil: evidence for Paleoproterozoic collision and collapse in the Quadrilátero Ferrífero. Precambrian Research, 90:29-58.

Almeida F.F.M. 1977. O Cráton do São Francisco. Revista Brasileira de Geociências, 7:285-295.

Basilici G. \& Dal Bó P. 2014. Influence of subaqueous processes into the construction and accumulation of an aeolian sand sheet: Upper Tulum Valley (San Juan Province, Western Argentina). Earth surface processes and landforms, 39:1014-1029.

Bristow C.S., Jol H.M., Augustinus P., Wallis I. 2010. Slipfaceless 'whaleback' dunes in a polar desert, Victoria Valley, Antarctica: Insights from ground penetrating radar. Geomorphology, 114:361-372.
Brookfield M.E. 1977. The origin of bounding surfaces in ancient aeolian sandstones. Sedimentology, 24:303-332.

Chakraborty T. \& Chakraborty C. 2001. Eolian-aqueous interactions in the development of a Proterozoic sand sheet: Shikaoda Formation, Hosangbad, India. Journal of Sedimentary Geology, 71:107-117.

Chaves M.L.S.C \& Brandão P.R.G. 2004. Diamante variedade carbonado na Serra do Espinhaço (MG/BA) e sua enigmática gênese. Revista Escola de Minas, 57:33-38

Chemale F., Dussin I.A., Alkmim F.F., Martins M.S., Queiroga G., Armstrong R., Santos M.N. 2012. Unravelling a Proterozoic basin history through detrital zircon geochronology: The case of the Espinhaço Supergroup, Minas Gerais, Brazil. Gondwana Research, 22:200-206. 
Clemmensen L.B. \& Dam G. 1993. Aeolian sand-sheet deposits in the Lower Cambrian Neksø Sandstone Formation, Bornholm, Denmark: sedimentary architecture and genesis. Sedimentary Geology, 83:71-85.

Cowan G. 1993. Identification and significance of aeolian deposits within the dominantly fluvial Sherwood Sandstone Group of the dominantly fluvial Sherwood Sandstone Group of the East Irish Sea Basin U.K. In: North C.P. \& Prosser D.J. (eds.) Characterization of Fluvial and Aeolian Reservoirs. Special Publication, 73:231-245.

Dussin I.A. \& Dussin T.M. 1995. Supergrupo Espinhaço: modelo de evolução geodinâmica. Geonomos, 3:19-26.

Eriksson K.A. \& Simpson E.L. 1998. Controls on spatial and temporal distribution of Precambrian eolianites. Sedimentary Geology, 120:275-294.

Fielding C.R. 2006. Upper flow regime sheets, lenses and scour fills: extending the range of architectural elements for fluvial sediment bodies. Sedimentary Geology, 190:227-240.

Fogaça A.C.C., Almeida-Abreu P.A., Schorscher H.D. 1984. Estratigrafia da sequência supracrustal arqueana na porção mediana central da Serra do Espinhaço, MG. In: 33 Congresso Brasileiro de Geologia, Anais, p. 2652-2667.

Fryberger S.G. \& Schenk C.J. 1988. Pin stripe lamination: a distinctive feature of modern and ancient eolian sediments. Sedimentary Geology, 55:1-15.

Hunter R.E. 1977. Basic type of stratification in small eolian dunes. Sedimentology, 24:361-367.

Hunter R.E. 1981. Stratification styles in eolian sandstones: some Pennsylvanian to Jurassic examples from western interior U.S.A. In: Ethridge F.G. \& Flores R.M. (eds.) Recent and Ancient Non marine Depositional Environments: Models for Exploration. SEPM Special Publication, 31:315-329.

Jain M., Tandon S.K., Singhvi A.K., Mishra S., Bhatt S.C. 2005. Quaternary alluvial stratigraphical development in a desert setting: a case study from the Luni River basin, Thar Desert of western India. Fluvial Sedimentology VII. IAS, Special Publication, 35:349-371.

Kocurek G. 1996. Desert aeolian systems. In: Reading H.G. (eds.) Sedimentary environments: Processes, Facies and Stratigraphy. Blackwell, Oxford, 3 ed., p. 125-153.

Kocurek G. \& Havholm K.G. 1993. Eolian Sequence Stratigraphy a conceptual framework. In: Weimer P. \& Posamentier H.W. (eds.) Siliciclastic sequence stratigraphy: recent developments and aplications. American Association of Petroleum Geologists, 58, p. 393-409.

Kocurek G. \& Nielson J. 1986. Conditions favourable for the formation of warm-climate aeolian sand sheets. Sedimentology, 33:795-816.

Krapf C.B., Stanistreett I., Stollhofen H. 2005. Morphology and FluvioAeolian Interaction of the Tropical Latitude, Ephemeral BraidedRiver Dominated Koigab Fan, North-West Namibia. In: Blum M.D. Marriott S.B., Leclair S.F. (eds.) Fluvial Sedimentology VII. International Association of Sedimentologists. Special Publication, 35:99-120.

Lea P.D. \& Waythomas C.F. 1990. Late-Pleistocene eolian sand sheets in Alaska. Quaternary Research, 34:269-281.

Lopes-Silva L. \& Knauer L.G. 2011. Posicionamento Estratigráfico da Formação Bandeirinha na Região de Diamantina, Minas Gerais: Grupo Costa Sena ou Supergrupo Espinhaço? Geonomos, 19:131-151.

Mahaney W.C. 2000. Atlas of sand grain surface textures and applications. Oxford University Press. $141 \mathrm{p}$.
Martins-Neto M.A. 2000. Tectonics and sedimentation in a paleo/ mesoproterozoic rift-sag basin in Espinhaço basin, southeastern Brazil. Sedimentary Geology, 103:147-173.

Miall A.D. 1985. Architectural-element analysis: a new method of facies analysis applied to fluvial deposits. Earth-Science Reviews. 22:261-308.

Mountney N.P. 2006. Aeolian facies model. In: Posamentier H.W. \& Walker R.G. (eds.) Facies models revisited. Society for Sedimentary Geology, Special Publication, 84:19-83.

Mountney N.P. \& Howell J. 2000. Aeolian architecture, bedform climbing and preservation space in the Cretaceous Etjo Formation, NW Namibia. Sedimentology, 47:825-849.

Mountney N.P. \& Russell A.J. 2004. Sedimentology of cold-climate aeolian sand sheet deposits in the Askja region of northeast Iceland. Sedimentary Geology,166:223-244

Nielson J. \& Kocurek G. 1986. Climbing Zibars of the Algodones. Sedimentary Geology, 48:1-15

Rodríguez-López J.P., Liesa C.L., Van Dam J., Lafuente P., Arlegui L., Ezquerro L., De Boer P.L. 2012. Aeolian construction and alluvial dismantling of a fault-bounded intracontinental aeolian dune field (Teruel Basin, Spain); a continental perspective on Late Pliocene climate change and variability. Sedimentology, 59:1536-1567.

Rodriguéz-López J.P., Melendez N., De Boer P.L., Poppe L., Soria A.R. 2010. The action of wind and water in a mid-Cretaceous subtropical erg-margin system close to the Variscan Iberian Massif, Spain. Sedimentology, 57:1315-1356.

Santos M.N., Chemale Jr. F., Dussin I.A., Martins M., Assis T.A.R., Jelinek A.R., Guadagnin F., Armstrong R. 2013.Sedimentological and Paleoenvironmental Constraints of the Statherian and Stenian Espinhaço Rift System, Brazil. Sedimentary Geology, 290:47-59.

Silva R.R. 1998. As bacias proterozóicas do Espinhaço e São Francisco em Minas Gerais: Uma abordagem do ponto de vista da estratigrafia de sequências. Geonomos, 6:1-12

Simplicio F. 2013. Formação Bandeirinha, região de Diamantina (MG): Um exemplo, no proterozoico, de lençol de areia eólica. MS Dissertation, Instituto de Geociências, Universidade Estadual de Campinas, Campinas, 74p

Tooth S. 2000. Process, form and change in dry land rivers: a review of recent research. Earth-Science Reviews, 51:67-107.

Trewin N.H. 1993. Mixed aeolian sand sheet and fluvial deposits in the Tunblagoda Sandstone, Western Australia. In: North C.P. \& Prosser D.J. (eds.) Characterization of fluvial and aeolian reservoirs. Geological Society of America, Special Publication, 73:219-230.

Walker R.G. 2006.Facies models revisited: introduction. In Posamentier H.W. \& Walker R.G. (eds.) Facies models revisited. Society for Sedimentary Geology, Special Publication, 84:1-19.

Wang Z.T., Sun Q.F., Ren X.Z., Wang T., Chen F.H. 2009. Pseudofeathery dunes in the Kumtagh desert reclassified as linear dunes and zibars. Aeolian Research, 1:87-89.

Worden R.H. \& Burley S.D. 2003. Sandstone Diagenesis: The Evolution of Sand to Stone. In: Burley S.D. \& Worden R.H. (eds.) Sandstone Diagenesis: Recent and Ancient, Blackwell, Oxford. p. 1-44.

Arquivo digital disponível on-line no site www.sbgeo.org.br 